\title{
LETTERS
}

\section{More research needed for health systems infrastructure funding}

We read with great interest Teja and colleagues' analysis of capital spending in Canada's public health care system. ${ }^{1}$ There has been insufficient research into health sector capital financing, despite its clear significance to health system performance. We welcome this recent contribution in this under-researched area of health policy and health services planning.

First, we are not in disagreement that "capital investment has both varied more and declined in recent years, suggesting underinvestment and inequity in health care capital." ${ }^{1}$ However, we have concerns with the analysis and the evidence presented to support the conclusions made by the authors.

The authors claim that "removing the capital gains tax on donations of real estate or private company shares could stimulate a substantial increase in charitable giving among Canadians, including to charitable organizations raising money for health care capital expenditures." ${ }^{1}$ No peer-reviewed literature is cited. We are also not aware of any literature that supports the idea that public health care systems would be well served by relying increasingly on charitable donations. On the contrary, the evidence suggests that the performance of publicly financed systems is most likely to benefit from public
- not private - finance. ${ }^{2}$ It would seem, then, that the remedy is to ensure consistent public capital investment. One such mechanism might be for the federal government to require consistent capital spending plans from provincial governments in order to maintain eligibility for federal transfer payments.

The authors present the idea that provinces should consider "partnering more frequently with agencies that have expertise in capital funding." ${ }^{1}$ We assume that the authors are referring broadly to public-private partnership models (P3s). However, the article does not provide an empirical basis on which to make this conclusion. The authors acknowledge, based on the limited peerreviewed literature they cite, that P3s have had mixed results.

More inclusive examination of the literature reveals that $\mathrm{P} 3 \mathrm{~s}$ are less cost efficient for government, because of higher private-sector financing costs and substantial "transaction costs" borne by government to initiate, negotiate and manage the $\mathrm{P} 3$ relationship over the life of the contract. $^{3,4}$ In Ontario, for example, the Office of the Auditor General of Ontario's 2014 review of 75 infrastructure projects found the extensive use of short-term P3 construction financing has been $\$ 6.5$ billion (or 14 times) more costly than public borrowing. There is also evidence of compromised infection control when parts of the hospital workforce, including cleaning staff, are outsourced - a common prac- tice with P3s. ${ }^{5}$ This is significant in its own right, but especially amid the coronavirus disease 2019 pandemic.

We welcome further discussion, a systematic review of existing studies and new research on this important topic.

\section{Andrew R. Longhurst MA}

PhD student, Department of Geography, Simon Fraser University, Burnaby, BC

\section{Rita K. McCracken MD PhD}

Assistant professor, Department of Family Practice, University of British Columbia, Vancouver, BC

Cite as: CMAJ 2020 August 10;192:E930. doi: $10.1503 / \mathrm{cmaj} .76252$

\section{References}

1. Teja B, Daniel I, Pink GH, et al. Ensuring adequate capital investment in Canadian health care. CMAJ 2020;192:E677-83

2. Tuohy $\mathrm{CH}$, Flood $\mathrm{CM}$, Stabile M. How does private finance affect public health care systems? Marshaling the evidence from OECD nations. $J$ Health Polit Policy Law 2004;29:359-96.

3. Boardman AE, Siemiatycki M, Vining AR. The theory and evidence concerning public-private partnerships in Canada and elsewhere. Calgary: School of Public Policy, University of Calgary; 2016.

4. Whiteside H. Purchase for profit: public-private partnerships and Canada's public health-care system. Toronto: University of Toronto Press, Scholarly Publishing Division; 2015.

5. Zuberi D. Cleaning up: how hospital outsourcing is hurting workers and endangering patients. Ithaca (NY): Cornell University Press; 2013.

Competing interests: Andrew Longhurst is employed by the Health Sciences Association of British Columbia. 